\title{
EVOLUÇÃO DO PROCESSO EROSIVO DA BACIA DOS RIOS ARICA-AÇU E ARICA-MIRIM, MT, ATRAVÉS DE ANÁLISE MULTITEMPORAL
}

\author{
SIMONE KOZCIAK*
}

\author{
DISSERTAÇÃO DE MESTRADO - Programa de Pós-Graduação em Geologia - UFPR \\ DATA DE DEFESA: 14 abr. 2000
}

\begin{abstract}
A erosão dos solos causa uma gama de impactos ambientais, desde sua própria degradação até problemas ambientais de forma geral. Os problemas iniciam no local onde ocorrem, estendendo-se para grandes áreas, como por exemplo, o material em excesso que é erodido em uma bacia hidrográfica, e pode causar o assoreamento dos rios e reservatórios. A região do Pantanal constitui-se em um ecossistema altamente sensitivo à atividade antrópica, e durante as últimas décadas, verificaram-se importantes transformações nos solos, principalmente nas regiões elevadas do pantanal. Uma intensa denudação do solo e sua rápida erosão vem sendo observada. Este trabalho tem por objetivo fazer a estimativa, nos últimos 30 anos, de perdas de solo por erosão laminar em duas sub-bacias do rio Cuiabá, usando o método quantitativo da Equação Universal de Perdas do Solo (EUPS). Os principais fatores que influenciam a erosão do solo foram aplicados em Sistema de Informações Geográficas, através de mapas temáticos, e com o cruzamento desses mapas obteve-se o valor de A, que é a perda média anual do solo em toneladas por hectare por
\end{abstract}

ano. Uma análise multitemporal, por meio de dados de cartas topográficas (1966) e imagens de satélite (1985 e 1996) foi realizada para obtenção dos dados de uso e ocupação do solo, fator que influencia a erosão. Observou-se uma grande mudança na cobertura do solo ocasionada principalmente por intervenção antrópica. Esta, conseqüentemente, causou um aumento nos índices de erosão nas duas bacias estudadas. O índice tolerável de perdas de solo, para cada tipo encontrado na região estudada, foi analisado a partir dos dados obtidos durante o desenvolvimento do trabalho, constatando-se um aumento significativo nas áreas com perdas acima do índice tolerável para cada solo. Os valores foram analisados de forma que indicassem a perda média anual por bacia de drenagem. A quantificação do material erodido em cada bacia é de fundamental importância para uma região como a do Pantanal, fortemente influenciada pelos regimes de inundações. O uso do SIG permitiu obter resultados rápidos e eficientes e, também, a viabilização dos dados que poderão ser usados e manipulados para geração de outros mapas temáticos. 